\title{
New observations indicate the possible presence of permafrost in North Africa (Djebel Toubkal, High Atlas, Morocco)
}

\author{
Gonçalo Vieira ${ }^{1}$, Carla Mora ${ }^{1}$, and Ali Faleh ${ }^{2}$ \\ ${ }^{1}$ Centre for Geographical Studies, IGOT, Universidade de Lisboa, Portugal \\ ${ }^{2}$ Université Sidi Mohamed Ben Abdellah, Fès, Morocco \\ Correspondence to: Gonçalo Vieira (vieira@ campus.ul.pt)
}

Received: 11 October 2016 - Discussion started: 27 October 2016

Revised: 3 June 2017 - Accepted: 8 June 2017 - Published: 21 July 2017

\begin{abstract}
Relict and present-day periglacial features have been reported in the literature for the upper reaches of the High Atlas mountains, which is the highest range in North Africa (Djebel Toubkal - $4167 \mathrm{~m}$ a.s.l.). A lobate feature in the Irhzer Ikhibi south at $3800 \mathrm{~m}$ a.s.l. has been previously interpreted as an active rock glacier, but no measurements of ground or air temperatures are known to exist for the area. In order to assess the possible presence of permafrost, we analyse data from June 2015 to June 2016 from two air temperature measurement sites at 2370 and $3210 \mathrm{~m}$ a.s.l. and from four ground surface temperature (GST) sites at 3220, 3815, 3980 and $4160 \mathrm{~m}$ a.s.l. to characterize conditions along an altitudinal gradient along the Oued Ihghyghaye valley to the summit of the Djebel Toubkal. GSTs were collected at $1 \mathrm{~h}$ intervals, and the presence of snow cover at the monitoring sites was validated using Landsat 8 and Sentinel-2 imagery. Two field visits allowed for logger installation and collection and for assessing the geomorphological features in the area. The results show that snow plays a major role on the thermal regime of the shallow ground, inducing important spatial variability. The lowest site at $3220 \mathrm{~m}$ had a thermal regime characterized by frequent freeze-thaw cycles during the cold season but with few days of snow. When snow settled, the ground surface remained isothermal at $0^{\circ} \mathrm{C}$, indicating the absence of permafrost. The highest sites at 3980 and $4160 \mathrm{~m}$ a.s.l. showed very frequent freeze-thaw cycles and a small influence of the snow cover on GST, reflecting the lack of snow accumulation due to the wind-exposed settings on a ridge and on the summit plateau. The site located at $3815 \mathrm{~m}$ in the Irhzer Ikhibi south valley had a cold, stable thermal regime with GST varying from -4.5 to $-6{ }^{\circ} \mathrm{C}$ from December to March, under a continuous snow cover.
\end{abstract}

The site's location in a concave setting favours wind-driven snow accumulation and lower incoming solar radiation due to the shading effect of a ridge, inducing the conservation of a thick snow pack. The stable and low GSTs are interpreted as a strong indicator of the probable presence of permafrost at this site, which is an interpretation supported by the presence of lobate and arcuate features in the talus deposits. We present first results and further observations using geophysics, and borehole measurements are foreseen. This is the first time that probable permafrost has been reported from temperature observations in the mountains of North Africa.

\section{Introduction}

Permafrost occurrence in arid and semi-arid mountains plays a significant environmental role due to its influence on hydrology. Ice-bearing ground can act as a subsurface water reservoir contributing to streamflow even during the dry season. Its influence can therefore be significant for ecosystems and biodiversity, and, in some mountain areas, permafrost may have impacts on agriculture and grazing. However, permafrost research in high remote mountain regions is still in its early stages (see Rangecroft et al., 2013). In rapidly changing and sensitive mountain environments, permafrost niches can also provide special conditions allowing for the occurrence of biological refugia, which may include endemics and extremophiles of scientific significance (Hu et al., 2015; Jansson and Taş, 2014). Ice-rich permafrost and ground ice may also allow for palaeoenvironmental reconstruction (Lacelle and Vasil'chuk, 2013). Permafrost also plays a significant role for geomorphological dynamics in 
mountains, with a number of specific associated landforms and hazards linked to its warming and consequent thaw, such as rock falls and landslides (Haeberli et al., 2010).

The climatic importance of permafrost and the active layer has led to their classification as an Essential Climate Variable 9 by the Global Climate Observing System of the World Meteorological Organization (Smith and Brown, 2009). The International Permafrost Association maintains the Global Terrestrial Network for Permafrost (GTN-P), which includes over 1074 boreholes, but with only 31 sites in mountain permafrost settings (Biskaborn et al., 2015), which are still poorly assessed regions (Gruber and Haeberli, 2009) and are mainly found in the Alps.

Contemporary permafrost occurrence is known in the western Mediterranean region but is mostly constrained to small areas at high-altitude or shady sites. There are several active rock glaciers in the Pyrenees, and their distribution suggests that the lower limit of permafrost is around 2630$2700 \mathrm{~m}$ a.s.l. (Oliva et al., 2016b; Serrano et al., 2009). Geophysical and temperature measurements compiled from several authors by Serrano et al. (2009) suggest that continuous permafrost occurs above around $3000 \mathrm{~m}$ a.s.l. In the Sierra Nevada $\left(37^{\circ} 03^{\prime} \mathrm{N}, 03^{\circ} 19^{\prime} \mathrm{W}\right)$ an isolated patch of permafrost and a very small rock glacier lobe have been observed in the north-facing Veleta cirque at $3150 \mathrm{~m}$ a.s.l., protected by a steep rock wall and reflecting relict conditions associated with buried ice (Tanarro et al., 2001). However, a deep borehole in the summit area of the Veleta peak (3380 m a.s.l.) indicates that permafrost is absent, and mean annual ground temperatures were $3.2^{\circ} \mathrm{C}$ at $0.6 \mathrm{~m}$ and $2{ }^{\circ} \mathrm{C}$ at $20 \mathrm{~m}$ depth (Oliva et al., 2016a), indicating that altitude is perhaps less important than terrain characteristics for the conservation of permafrost.

Periglacial features are widespread in the High Atlas (Hughes et al., 2011) and have been described for the Central High Atlas by Couvreur (1966), who has reported active solifluction above $2200 \mathrm{~m}$ a.s.l. The same author stated that permafrost was absent in that part of the High Atlas and noted that there is a strong lithological control on the types of periglacial features. For the western High Atlas, Chardon and Riser (1981) found the limit of frost activity to be around $2500 \mathrm{~m}$ and considered that frost action dominates the morphogenesis above $3000 \mathrm{~m}$. In a study on sandstone weathering, Robinson and Williams (1992) reported air temperature minima ranging from -10 to $0^{\circ} \mathrm{C}$ in winter and temperatures as low as $-20^{\circ} \mathrm{C}$ at $2000 \mathrm{~m}$ a.s.l. The only landforms pointing towards a permafrost-related morphogenesis described in the literature are rock glaciers, as reported for the High Atlas by Dresch (1941), Wilche (1953) and Chardon and Riser (1981). Most of them are relict features and at least one case, the Arroumd rock deposit near Imlil, has recently been reinterpreted as a very large rock slide (Hughes et al., 2014). The only reference we found for active permafrost-related landforms is Chardon and Riser (1981), who interpret a lobate feature in the Irhzer Ikhibi south at $3800 \mathrm{~m}$ a.s.l. as being an active rock glacier. However, there are no recent studies and the literature lacks direct observations and quantitative data indicating the presence of permafrost. To our knowledge, the only direct thermal observation of permafrost in all of Africa is from Mount Kilimanjaro, where permafrost has been reported at $5785 \mathrm{~m}$ a.s.l. with ground temperatures of $-0.03{ }^{\circ} \mathrm{C}$ at $3 \mathrm{~m}$ depth (Yoshikawa, 2013).

Given the climate change scenarios that the Mediterranean regions are facing, which are marked by warming and a decrease in precipitation (Giorgi and Lionello, 2007; Montanari, 2013; Simonneaux et al., 2015), permafrost should be close to disappearing in most Mediterranean mountains. The subsurface nature of permafrost and the presence of a thawed surface layer in the warmer season (the active layer) strongly limit its identification, characterization and mapping, especially in remote mountain areas (Gruber and Haeberli, 2009).

Our study contributes towards solving the question of the presence of permafrost in North Africa and is an exploratory step towards an in-depth assessment aiming at the characterization and modelling of permafrost in the High Atlas. To carry out this initial assessment, we have installed a set of ground surface temperature (GST) and air temperature data loggers across an altitudinal gradient from $3200 \mathrm{~m}$ to the summit of the Djebel Toubkal at $4167 \mathrm{~m}$ to characterize the ground temperature regime and heat exchange at the groundatmosphere interface. The detailed analysis of the GSTs provides insight on the energy balance at the ground surface and its influence on the thermal regime of the underlying ground.

\section{Study area}

The Djebel Toubkal is located in the western High Atlas $\left(31^{\circ} 4^{\prime} \mathrm{N}, 7^{\circ} 55^{\prime} \mathrm{W}\right)$ and is the highest mountain in North Africa at $4167 \mathrm{~m}$ a.s.l. (Fig. 1). The Atlas Mountains consist of a series of ranges and plateaus extending from southwest Morocco to northern Tunisia across more than $2400 \mathrm{~km}$ (Mark and Osmaston, 2008). In Morocco, the Atlas Mountains include, from north to south, the Middle Atlas (Djebel Bou Naceur, $3340 \mathrm{~m}$ ), the High Atlas (Djebel Toubkal, $4167 \mathrm{~m}$ ) and the Anti-Atlas (Djebel Sirwa, $3304 \mathrm{~m}$ ). The High and Middle Atlas are intracontinental fold-thrust belts located in the foreland of the Rif (Arboleya et al., 2004). The three major massifs in the High Atlas are, from west to east, the Djebel Toubkal massif, the Irhil M'Goun massif (4071 m) and the Djebel Ayachi (3751 m).

The climate in the High Atlas is influenced by the Atlantic Ocean to the west, the Mediterranean Sea to the north and the Sahara desert to the south, resulting in a semi-arid to arid climate (Knippertz et al., 2003; Marchane et al., 2015). The rainy season lasts from November to April, and the dry season coincides with the summer, reflecting the Mediterranean style of the climate (N'da et al., 2016). Annual rainfall exceeds $600 \mathrm{~mm}$ above $700 \mathrm{~m}$, and summer precipitation is mostly convective. Boudhar et al. (2016) report an aver- 
age annual precipitation of $520 \mathrm{~mm}$ between 1989 and 2010 in Oukaimeden at $3200 \mathrm{~m}$ elevation. Snow is present from November to April or May in the highest parts of the mountains, but with irregular regimes (Badri et al., 1994; Peyron, 1980), and is rarely continuous at mid-altitude, with snowfall and subsequent melt events sometimes happening within a few days. However, in the highest reaches, snow cover lasts for several weeks to months (Boudhar et al., 2009). Snowmelt contributes to $15-50 \%$ of the stream flow in the Tensift catchment, thus playing a significant role for irrigation (Boudhar et al., 2009). The low atmospheric humidity and typically subfreezing temperatures above $3000 \mathrm{~m}$ favour losses by sublimation, which can account for up to $44 \%$ of snow ablation, while at lower altitudes melting prevails (Schulz and de Jong, 2004). The only perennial snow patch in North Africa is located below the north-facing cliffs of the Tazaghart plateau (3980 m a.s.l.), close to the Toubkal. This feature is described in various recent papers and was identified by Dresch (1941) together with other periglacial features (see Hughes, 2014). Its presence may be related to the high snow accumulation on the plateau above, together with the sheltering effect of the steep north-facing cliff face.

The present study was conducted in the upper reaches of the Oued Ihghyghaye valley, between the marabout of Sidi Chamharouch and the summit of Djebel Toubkal (Fig. 1). The lithology of the study area is characterized by Precambrian volcanics, such as pyroxene-bearing doleritic basalts and megaporphyric basalts of the Sidi Chamharouch formation (Zahour et al., 2016) and andesites in the Djebel Toubkal (Cheggour, 2008; Rauh, 1952; Ros et al., 2000). The area has a typical alpine relief with sharp ridges rising above $3500 \mathrm{~m}$ and long deep valleys. The upper catchments show evidence of late Pleistocene glaciation with landforms such as roche moutonées and moraines (Chardon and Riser, 1981; Hannah et al., 2016; Hughes et al., 2011; Hughes and Woodward, 2008; Mark and Osmaston, 2008; de Martonne, 1924). Extensive talus slopes and debris cones, together with widespread evidence of frost shattering, mark the landscape above $3000 \mathrm{~m}$.

Our study area lies between the Neltner (NLT) mountain hut of the Club Alpin Français de Casablanca and the Toubkal summit along the Irhzer Ikhibi south valley, which is the main climbing route. The valley is about $1400 \mathrm{~m}$ long and is a hanging tributary of the Oued Ihghyghayene valley, southeastwards of the Neltner hut above a rocky knoll with glacier polished outcrops at 3350-3400 m. Above the knoll, the valley floor is steep and is filled with accumulations of large boulders. Towards the east there are talus slopes, which are matrix-supported accumulations of decimetric to metric angular clasts (Fig. 2). At ca. $3800 \mathrm{~m}$ there are small lobate forms and incipient arcuate ramparts in the rock sediments, possibly indicating active periglacial dynamics, either by solifluction or permafrost creep. Chardon and Riser (1981) interpret this as an active rock glacier, but there is no steep front and no clearly defined debris body, so we do not sup-

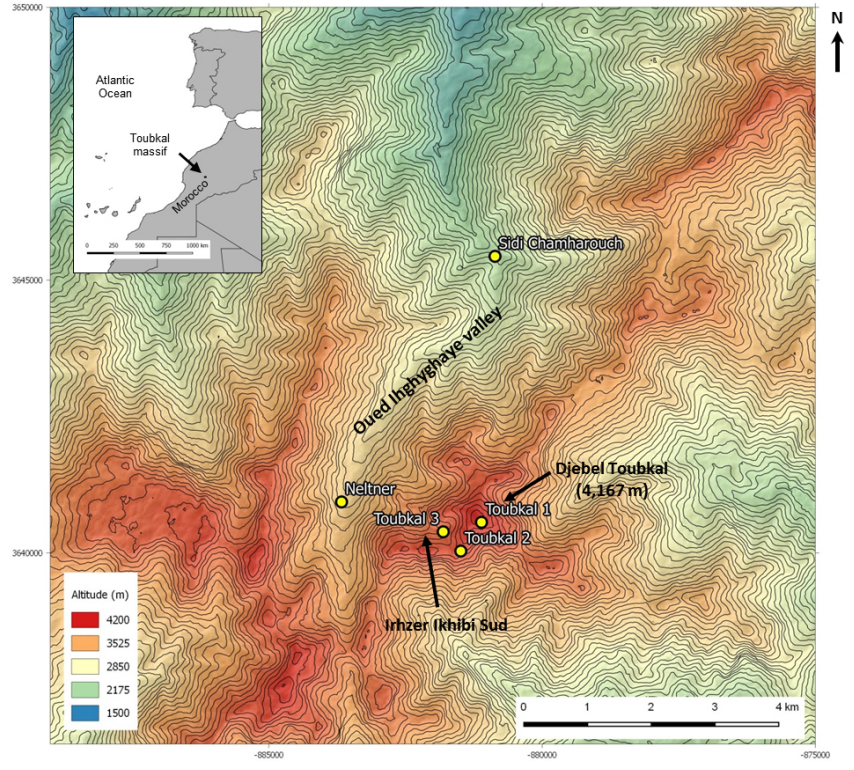

Figure 1. Location and topography of the Toubkal massif study area. Yellow circles are the locations of the data loggers. Contour equidistance is $50 \mathrm{~m}$.

port this interpretation. No springs have been observed near the talus slope. The valley has dissymmetric sides, with slope angles around $15-25^{\circ}$ in the south-facing slope and $20-40^{\circ}$ prevailing in the north-facing slope. The valley headwalls are $30-40^{\circ}$ steep, with scarps and free-rock faces occurring at $3800-3900 \mathrm{~m}$ in the north- and west-facing slopes. Above the scarps, slope angles are $15-30^{\circ}$ and the surfaces are mantled with angular clasts and boulders, with a similar situation in the north slope of the Irhzer Ikhibi south. The southern ridge rises above $3900 \mathrm{~m}$, shading the valley floor in winter. Snow patches frequently remain in the valley until June, especially in the Toubkal slope. Local guides confirm that snow accumulates due to wind redistribution from the pass during the cold season and that they have not observed avalanches at the site. Google Earth imagery allows identifying numerous debris-mantled slopes and taluses with flow-like lineaments around the Toubkal, suggesting creep, and small rock glacierlike features can also be seen. There are solifluction lobes at the Irhzer Ikhibi north pass at $3900 \mathrm{~m}$, north of the Toubkal.

\section{Methods}

\subsection{Air and ground surface temperature monitoring}

Air temperature, relative humidity and ground surface temperature data loggers were installed in June 2015 from Sidi Chamharouch $(2370 \mathrm{~m})$ to Djebel Toubkal (4160 m a.s.1.) across an altitudinal transect, aiming to characterize the ground and air temperatures for 2015-2016 at an hourly resolution. We used Hobo Pro v2 loggers with an accuracy of 


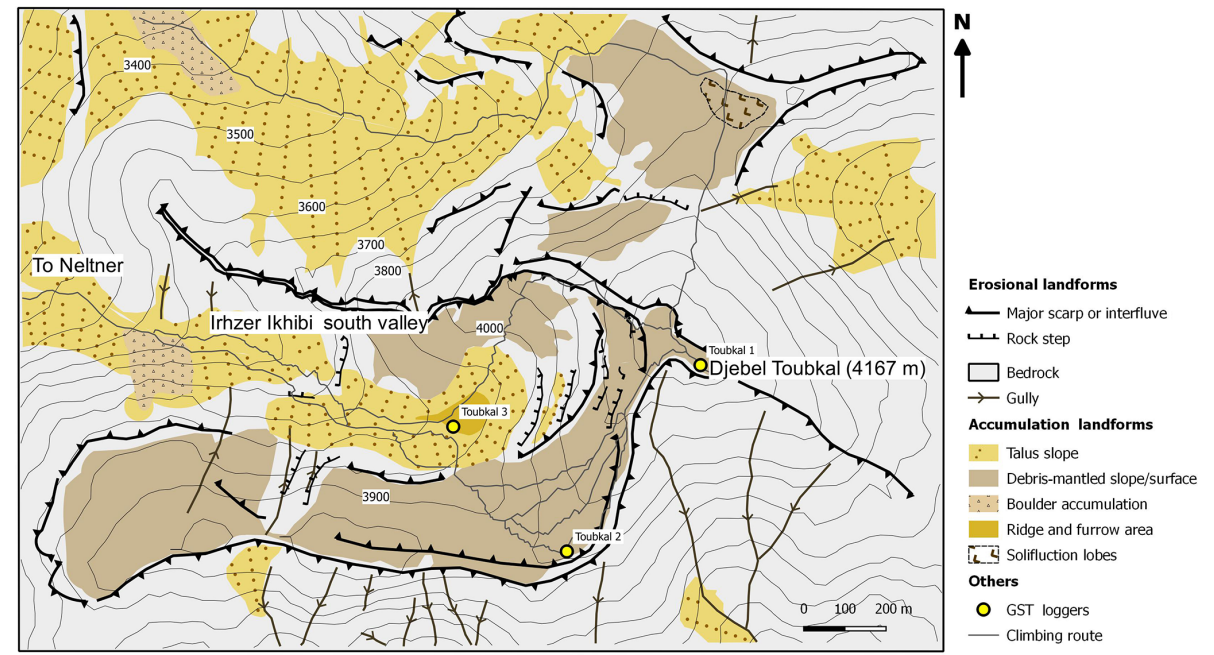

Figure 2. Geomorphological sketch map of the Toubkal massif (see legend).

Table 1. Temperature data loggers installed in the High Atlas. Variables: GST, ground surface temperature; AT, air temperature; $\mathrm{RH}$, relative humidity.

\begin{tabular}{lllll}
\hline Sites (abbrev.) & $\begin{array}{l}\text { Altitude } \\
\text { (m a.s.l) }\end{array}$ & Logger model & Variables & $\begin{array}{l}\text { Interval } \\
\text { (h) }\end{array}$ \\
\hline Sidi Chamharouch & 2370 & Hobo Pro v2 & AT, RH & 1 \\
Neltner (NLT) & 3210 & Hobo Pro v2, & AT, RH, & 1 \\
Toubkal 3 (T3) & 3220 & Tidbit & GST & \\
Toubkal 2 (T2) & 3815 & Tidbit & GST & 1 \\
Toubkal 1 (T1) & 41680 & Tidbit & GST & 1 \\
\hline
\end{tabular}

$\pm 0.2^{\circ} \mathrm{C}$ to measure air temperature and relative humidity, installed in radiation shields at ca. $2 \mathrm{~m}$ height. One was installed close to a shop in Sidi Chamharouch $(2370 \mathrm{~m})$ and the other near the Neltner hut $(3210 \mathrm{~m})$. The positions of both sites were surveyed by local partners. A mini-logger iButton DS-1922L was installed at the summit of Djebel Toubkal $(4167 \mathrm{~m})$, in the iron trig point at the summit. However, this logger disappeared, so no data are available.

To measure GST, single channel Hobo Tidbit mini-loggers with an accuracy of $\pm 0.2^{\circ} \mathrm{C}$ were glued to the lower face of a $15 \times 15 \times 0.2 \mathrm{~cm}$ high diffusivity steel plate that maximizes contact with the soil particles and buried at $2-3 \mathrm{~cm}$ depth (see Ferreira et al., 2016). To check for temperature drift after retrieval, the loggers were tested at various temperatures $\left(-20\right.$ to $\left.39^{\circ} \mathrm{C}\right)$ and showed average differences lower than $0.1^{\circ} \mathrm{C}$, which are well within sensor precision. The data were corrected using the freezing autumn zero curtain as a reference temperature. Four such loggers were installed between the Neltner hut and the summit of Djebel Toubkal. The sites were selected to determine altitude control on GST. All loggers were installed in stony soils with a silty-sandy matrix, in flat areas on otherwise gentle slopes. The Neltner logger was
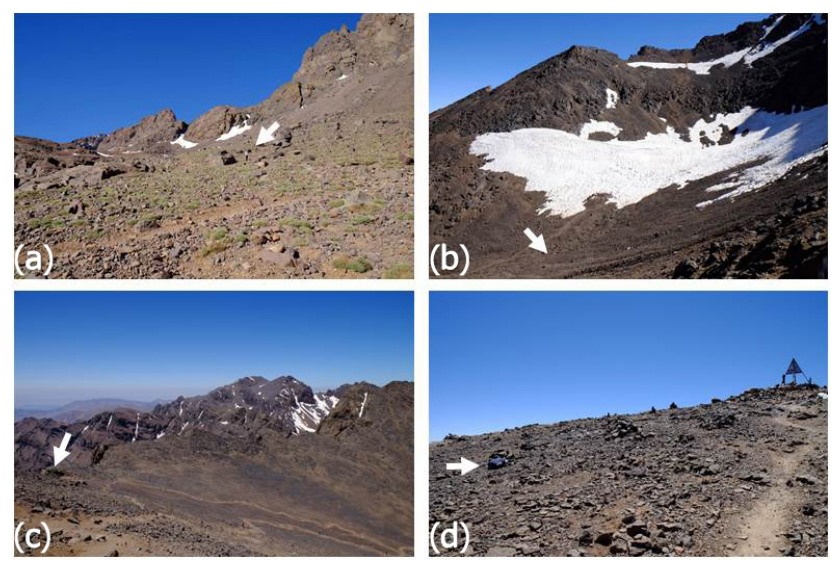

Figure 3. Locations of the ground surface temperature loggers (white arrows): (a) Neltner $(3220 \mathrm{~m})$, (b) Toubkal 3 (3815 m), (c) Toubkal 2 (3980 m) and (d) Toubkal 1 (4160 m).

installed above the hut in a bouldery diamicton. Toubkal 3 (T3) was in a bouldery diamicton in a valley, where snow accumulates. Toubkal 2 (T2) was installed in a debris-mantled slope, a few metres below a ridge crest. Toubkal 1 (T1) was installed in the rock debris on the Djebel Toubkal summit plateau, about $100 \mathrm{~m}$ from the summit. Given the known high spatial variability of GST in complex mountain settings (see Gubler et al., 2011), the interpretation of the results must be conducted with care, and this is why we tried to limit the differences in soil characteristics between sites. Details are provided in Table 1 and Fig. 3. Temperatures were recorded hourly from 16 June 2015 to 16 July 2016 with the objective of having a whole year of data, with one cold season. 


\subsection{Potential solar radiation modelling}

Slope angle and potential solar radiation were modelled using the algorithms provided by SAGA GIS 4.0, using a standard lumped atmospheric transmittance effect of $70 \%$ and the ASTER global digital elevation model version 2 from NASA, with a pixel size of $30 \mathrm{~m}$. The total potential solar radiation (direct + diffuse) was calculated for the whole year and also for July and December, in order to roughly assess the influence of solar radiation energy input on the ground temperature maxima at the different sites.

\subsection{Remote sensing snow cover characterization}

Although ground surface temperature regimes allow determining the presence of snow cover with a high degree of confidence, it was essential to demonstrate here that snow played a major role on GST and that it was present at some of the sites. To determine the presence or absence of snow cover, we used 18 scenes from Landsat 8 OLI and 2 scenes from Sentinel-2A, from 16 September 2015 to 14 June 2016. Landsat scenes were obtained at 16-day intervals, at $10 \mathrm{am}$ local time (USGS, 2016), and only one scene showed partial cloud cover. Sentinel-2 scenes at 10:30 am complement the series and confirmed the Landsat results. Pixel size is $30 \mathrm{~m}$ for Landsat 8 and $10 \mathrm{~m}$ for Sentinel-2 (ESA, 2015). We used full-resolution, georeferenced visible colour composites provided by USGS on EarthExplorer. The images allowed us to identify the general degree of snow cover at the monitoring sites. The interpretation had to be carried out with caution since the spatial resolution of the imagery is much lower than the microscale variability that may affect the monitoring sites. The snow conditions at each site were classified by visual inspection of the imagery as "no snow", "possible snow/snow margin", "snow" and "significant snow". The latter showed a homogeneous spectral signal of the snow surface across the areas surrounding the sensor sites, while the "snow" class still showed some spectral mixture, but clearly indicated the presence of snow. The classification was done on-screen in QGIS, using an overlay of elevation contours and the coordinates of the monitoring sites for better accuracy. Differences between snow and cloud cover were easily identifiable and clouds were rare.

\subsection{Climate series and extrapolation}

To put the period of June 2015 to July 2016 into a climate context, a long-term series of temperature and precipitation from a nearby meteorological station is needed. This allows comparing monthly records with the reference series in order to better frame the study period and discuss the results. However, the High Atlas has no long-term meteorological stations, and the regional network is very sparse. The only long-term meteorological data available are from Marrakesh (Menara) in the plains north of the mountain range
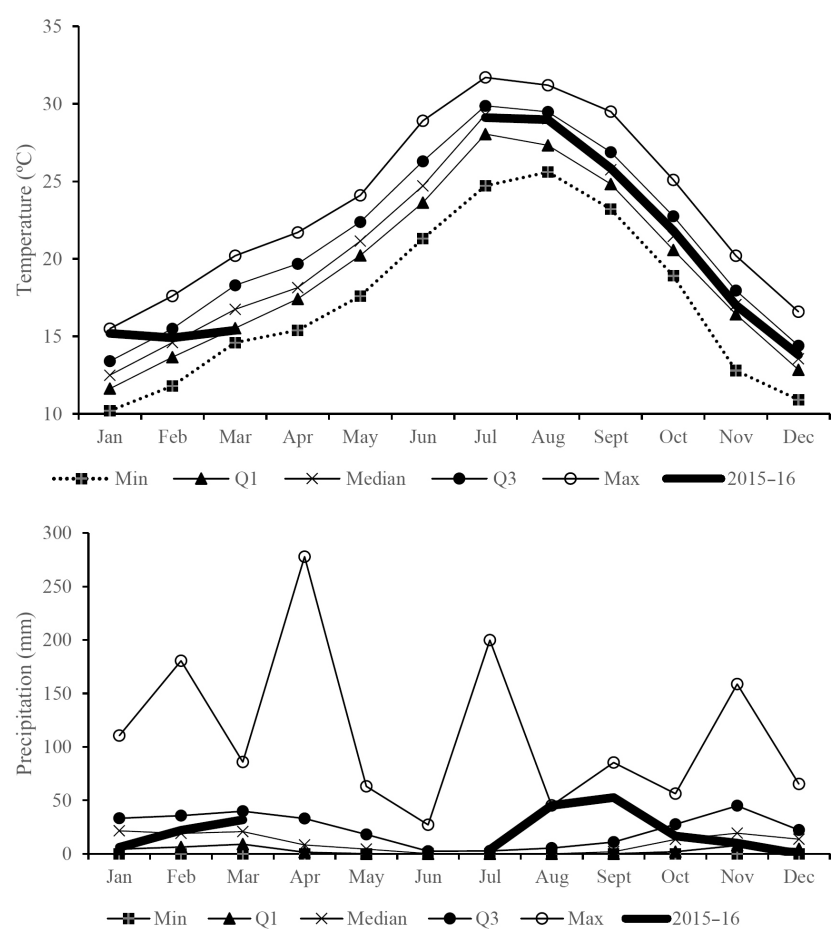

Figure 4. Statistics of mean annual monthly air temperature and precipitation at Menara (Marrakesh) from 1977 to 2015 and during the study period (July 2015-March 2016; thick black line). Data source: NCEI-GHCN.

at $468 \mathrm{~m}$ a.s.l. and about $65 \mathrm{~km}$ from the study site or from Ouarzazate, in the southern piedmont, at $1153 \mathrm{~m}$ a.s.l, but in a very dry setting. The Middelt station, located $350 \mathrm{~km}$ to the east of the Toubkal massif at $1515 \mathrm{~m}$ a.s.l., has very incomplete data. We used the more complete data series from Menara to compare the climate characteristics of the study period with a longer time series. The data were obtained from the custom Monthly Summaries of the Global Historical Climate Network (NCEI-GHCN) for 1977-2016. Before 1977 there are several gaps in the series.

\section{Results}

\subsection{Climate characteristics of the study period}

Climate records from Marrakesh (Menara - Fig. 4) for June 2015 to March 2016 (no data available afterwards) show that mean monthly air temperature from June to December was close to the median, but January was extremely warm, with a value $\left(15.2^{\circ} \mathrm{C}\right)$ close to the maximum $\left(15.5^{\circ} \mathrm{C}\right)$ of the period $1977-2015$ and well above the 3 rd quartile $\left(13.4^{\circ} \mathrm{C}\right)$. February with a mean of $14.9^{\circ} \mathrm{C}$ was between the median and the 3rd quartile, and in March the mean monthly temperature was close to the 1 st quartile, at $15.4^{\circ} \mathrm{C}$. Very high precipitation values were registered in August and September (close to the maximum) decreasing afterwards, with Novem- 


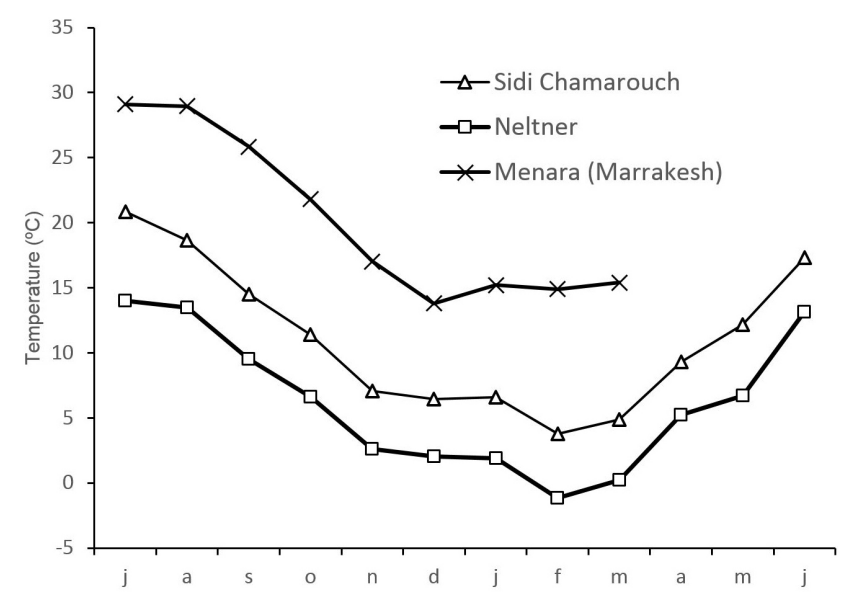

Figure 5. Mean monthly air temperatures from July 2015 to June 2016 in Marrakesh (Menara, $468 \mathrm{~m}$ ) and in Sidi Chamharouch (2370 m) and Neltner (3210 m).

ber to January being very dry, below the 1st quartile and close to the minimum. In February precipitation was close to the median and close to the 3rd quartile in March. The study period was initially characterized by a wet summer, followed by a dry autumn and early winter, which coincided with a very warm January, followed by a particularly cold and wet March.

The mean monthly air temperatures measured at Sidi Chamharouch and Neltner showed similar variations to those measured at Menara, with the exceptions of February and March, which were colder in the mountains (Fig. 5). The lowest mean air temperature was recorded at Neltner, $-1.2^{\circ} \mathrm{C}$ in February $2016\left(3.8^{\circ} \mathrm{C}\right.$ in Sidi Chamharouch), and the highest was measured in July $2015,14.0^{\circ} \mathrm{C}$ in Neltner $\left(20.9^{\circ} \mathrm{C}\right.$ in Sidi Chamharouch). The mean annual air temperature (MAAT) for July 2015 to June 2016 was $6.2^{\circ} \mathrm{C}$ at Neltner and $11.1^{\circ} \mathrm{C}$ at Sidi Chamharouch, which results in a lapse rate of $-0.59^{\circ} \mathrm{C} 100 \mathrm{~m}^{-1}$, a value close to the

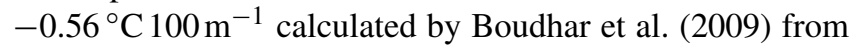
weather station data from Saada $(411 \mathrm{~m})$ and Oukaimeden $(2760 \mathrm{~m})$ for $1998-2005$. Extending the lapse rate obtained for our two stations to the summit results in a MAAT of $0.6^{\circ} \mathrm{C}$ there.

Reports from local guides indicate that the winter of 20152016 was anomalous regarding the snow conditions, with a very late onset of the snowpack in mid-February. This is confirmed by the remote sensing data (Fig. 6), which show snow in early October 2015 in the Toubkal massif, with a peak snow coverage in the 18 October 2015 scene, then decreasing progressively until early January when a short duration snow cover shows up, and melts again by 7 February. Significant snowfall only occurred between 7 and 23 February, covering the whole study area. The snow cover remained in the valley floors and shady concave areas until 11 April, but quickly melted from the ridges and south-facing slopes. In mid-May another large snowfall occurred, but the snow melted quickly within 2 weeks and by mid-June was completely gone from the study area.

\subsection{Ground surface temperatures}

Mean monthly ground surface temperatures (GSTs) in the Toubkal massif showed a similar annual regime at the four sites (Fig. 7), with the warmest month in June 2016 showing values from $13.5^{\circ} \mathrm{C}$ at $\mathrm{T} 2$ to $17.7^{\circ} \mathrm{C}$ at NLT. During the cold season mean monthly GSTs below $0^{\circ} \mathrm{C}$ were registered from November to March at the three higher sites, with NLT still showing a positive average in November. A stable mean GST below $-5^{\circ} \mathrm{C}$ was registered at T3 from December to March, while a minimum of $-4.5^{\circ} \mathrm{C}$ was measured in February at T1.

The daily absolute GST maxima and minima generally fit the regime of the monthly means (except at T3) and show very high amplitudes. A plateau in the curve for the daily maxima is visible from April to September, with T3 showing the highest values $\left(39.3\right.$ and $40.5^{\circ} \mathrm{C}$ in June and July 2016 respectively). At the same site, the stabilization of the absolute minima below $-4.4{ }^{\circ} \mathrm{C}$ in January and February 2016, as well as the sudden rise from $0^{\circ} \mathrm{C}$ in March to $31.3^{\circ} \mathrm{C}$ in April, are noteworthy. The mean annual GST (MAGST) showed a decrease with altitude with values of $6.0^{\circ} \mathrm{C}$ at NLT, $3.2^{\circ} \mathrm{C}$ at $\mathrm{T} 3,3.3{ }^{\circ} \mathrm{C}$ at $\mathrm{T} 2$ and $2.8{ }^{\circ} \mathrm{C}$ at $\mathrm{T} 1$, which is the summit of Toubkal (Fig. 8 and Table 2). Freezing degree days (FDDs) varied strongly, with a minimum number of FDDs at NLT (110), a maximum at T3 (779), and 325 and 499 at $\mathrm{T} 2$ and $\mathrm{T} 1$ respectively (Table 2). Thawing degree days (TDDs) ranged from 1536 at T1 to 2317 at NLT, with a general decrease with altitude. Modelled annual potential incoming solar radiation (Fig. 9 and Table 2) showed much higher values at the interfluve sites $\left(\mathrm{T} 1-2432 \mathrm{kWhm}^{-2}\right.$ and $\mathrm{T} 2-2631 \mathrm{kWhm}^{-2}$ ) than at the valley sites (NLT 1703 and T3 $-1892 \mathrm{kWh} \mathrm{m}^{-2}$ ), while July values were much more homogeneous at all sites, ranging from $223 \mathrm{kWh} \mathrm{m}^{-2}$ at NLT to $262 \mathrm{kWh} \mathrm{m}^{-2}$ at T1. December values were very low at the NLT and T3 (respectively 33 and $43 \mathrm{kWh} \mathrm{m}^{-2}$ ) reflecting shading by the high interfluves, while the ridge sites $\mathrm{T} 2$ and $\mathrm{T} 1$ showed higher values (respectively 185 and $133 \mathrm{kWh} \mathrm{m}^{-2}$ ).

Four altitudinal patterns of mean monthly GST occurred during the study period (Fig. 10). Group 1 includes the warm season (June, July and August) and shows decreasing GST with altitude, with T2 slightly colder than T1. Group 2 integrates the transition months, with May, September and October showing a similar continuous decrease of GST with altitude and a temperature difference of ca. $-0.47^{\circ} \mathrm{C} 100 \mathrm{~m}^{-1}$. Group 3 includes the cold season (January, February, March, November and December) and shows a general decreasing of GST with altitude, with T3 being the coldest site. Finally, April 2016 shows up as an outlier, with an inverted tempera- 

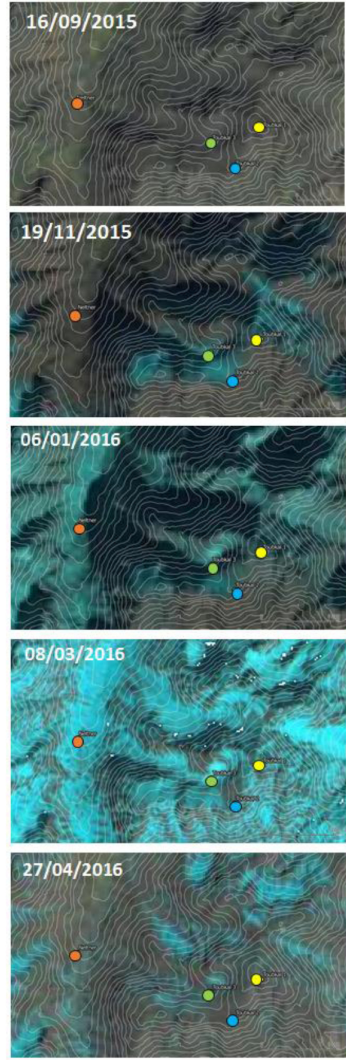

Neltner $\bigcirc \quad$ T3 0 T2 $\odot$ T1 $O$
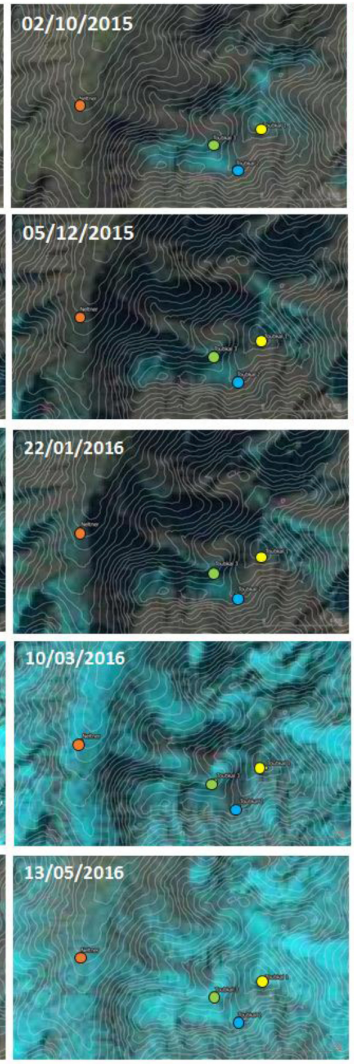
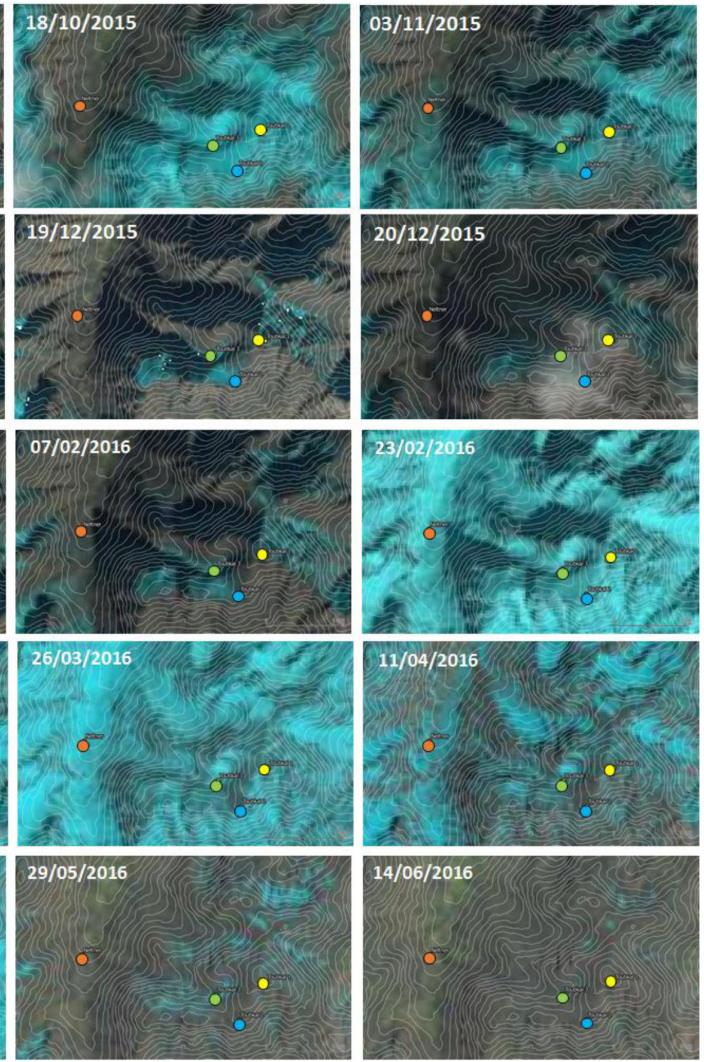

Figure 6. Satellite true colour composite scenes from Landsat 8 (USGS) and Sentinel-2 (ESA) used for assessing snow coverage at the monitoring sites (coloured dots, see legend) from September 2015 to June 2016. Light blue indicates snow cover and brown and green indicate snow-free terrain. Satellite imagery obtained from USGS EarthExplorer.

ture difference with altitude and with $\mathrm{T} 3$ as the warmest site (Group 4).

The hourly GST records allow for a more accurate analysis of the conditions influencing the monthly means and the assessment of the environmental controls on the ground thermal regime (Fig. 11). The first striking characteristic of the GST at the four sites is the large diurnal thermal amplitude range, especially from May to September with average amplitudes of $11.4-12^{\circ} \mathrm{C}$, except at T3, where average amplitudes of $19.7^{\circ} \mathrm{C}$ were registered. Maximum amplitudes were between 19.2 and $22.5^{\circ} \mathrm{C}$, except at $\mathrm{T} 3$, where amplitudes of $35^{\circ} \mathrm{C}$ were registered.

The cold season is clearly defined in the GST data, lasting from mid-October to the end of April, with May being a transition month. There are clear differences in GST regimes during the cold season. At NLT there was a long period from mid-October to mid-February with small thermal amplitudes and numerous freeze-thaw cycles. Afterwards, temperatures remained stable just below freezing until mid-April. At T3 the cold season was marked by subzero GST from mid-October to mid-April, with temperatures decreasing regularly until mid-December after an autumn zero curtain of about 2 weeks in late October. Then, temperatures dropped from around $-4.5^{\circ} \mathrm{C}$ and decreased irregularly to about $-6^{\circ} \mathrm{C}$, a situation which lasted until late March, when GST increased quickly and stabilized for about 10 days during the spring zero curtain. From mid-December to late March the diurnal amplitudes of GST at T3 were typically between 0.4 and $1.0^{\circ} \mathrm{C}$, with an average of $0.8^{\circ} \mathrm{C}$. The GST regime is especially significant in this paper and will be analysed in more detail below. The two upper sites, T2 and T1, had very similar GST regimes during the cold season, with the main differences being the number of freeze-thaw cycles. These occurred more frequently at $\mathrm{T} 2$, with lower maxima during the cold season at T1. Both sites show a short zero-curtain effect in late October. GST daily amplitudes from mid-December to mid-March averaged $5.2{ }^{\circ} \mathrm{C}$ at $\mathrm{T} 2$ and $4.8^{\circ} \mathrm{C}$ at $\mathrm{T} 1$ and were variable at NLT.

After an increase in GST in April 2016 there was significant cooling in May that lasted for 8 days in NLT and 19 days at T3. This cold spell resulted in a stabilization of the GST at $0.5^{\circ} \mathrm{C}$ at $\mathrm{NLT}$, at $0.2^{\circ} \mathrm{C}$ at $\mathrm{T} 3$, and at $0{ }^{\circ} \mathrm{C}$ at $\mathrm{T} 1$ (indicating the presence of snow) and in a cold but unstable regime at $\mathrm{T} 2$. 
Table 2. Ground temperatures, frost indices and modelled potential solar radiation in the monitoring sites of the Toubkal massif.

\begin{tabular}{|c|c|c|c|c|c|c|c|c|}
\hline & \multirow{2}{*}{$\begin{array}{l}\text { Altitude } \\
\text { (m a.s.l.) }\end{array}$} & \multirow{2}{*}{$\begin{array}{r}\text { MAGST } \\
\left({ }^{\circ} \mathrm{C}\right)\end{array}$} & \multirow{2}{*}{$\begin{array}{r}\text { FT } \\
\text { cycles } \\
(\text { No. })\end{array}$} & \multirow[t]{2}{*}{ FDD } & \multirow[t]{2}{*}{ TDD } & \multicolumn{3}{|c|}{$\begin{array}{l}\text { Potential solar radiation } \\
\qquad\left(\mathrm{kWh} \mathrm{m}^{-2}\right)\end{array}$} \\
\hline & & & & & & Annual & July & December \\
\hline Neltner (NLT) & 3220 & 6.0 & 62 & 110 & 2317 & 1703 & 230 & 49 \\
\hline Toubkal 3 (T3) & 3815 & 3.2 & 45 & 779 & 1936 & 1892 & 246 & 59 \\
\hline Toubkal 2 (T2) & 3980 & 3.3 & 143 & 325 & 1542 & 2631 & 264 & 126 \\
\hline Toubkal 1 (T1) & 4160 & 2.8 & 96 & 499 & 1536 & 2432 & 271 & 141 \\
\hline
\end{tabular}
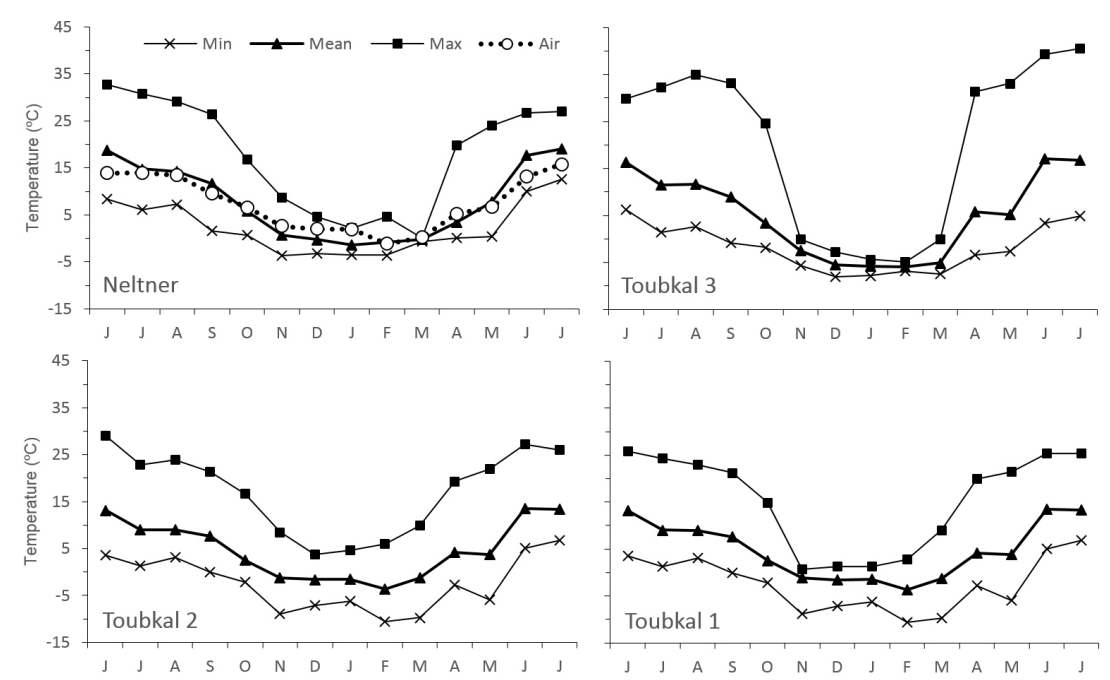

Figure 7. Monthly ground surface and air temperatures in the Djebel Toubkal massif from June 2015 to July 2016. Extremes are absolute monthly maximum and minimum temperatures.

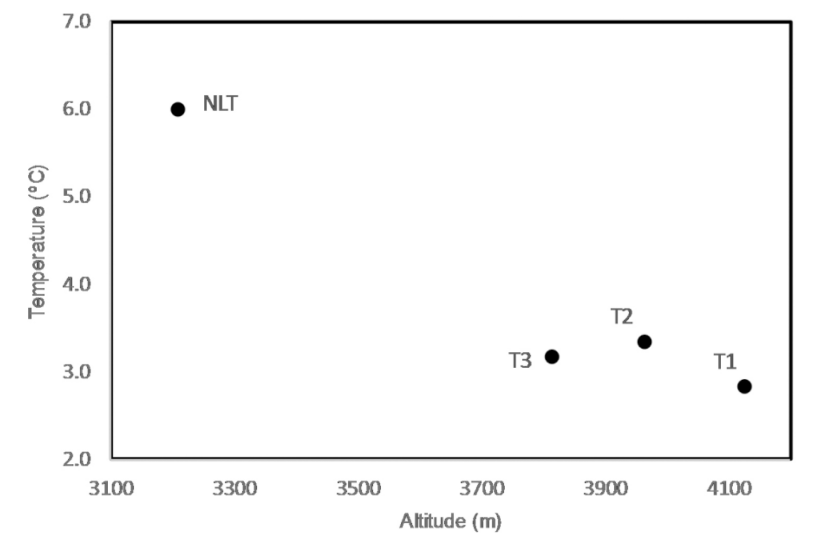

Figure 8. Mean annual ground surface temperatures versus altitude for the four monitored sites in the Djebel Toubkal massif.

\section{Discussion}

MAGST in the study area varied between 6.0 and $2.8^{\circ} \mathrm{C}$, values which are high when compared to mid-latitude mountains with permafrost. For example, Salvador Franch et al. (2011) indicate that the mean annual ground temperature in a shallow borehole with permafrost in the Sierra Nevada was $0.6^{\circ} \mathrm{C}$ at $0.05 \mathrm{~m}$ depth, while the PERMOS network in Switzerland consistently shows MAGST below the values measured in the High Atlas (PERMOS, 2016). There is a clear altitudinal control on the MAGST, but topographically driven site-specific factors, such as high snow accumulation and lower potential annual solar radiation, affect the spatial pattern and lower the surface temperatures, as was observed at T3. At this site, 779 FDDs were registered, in contrast with 325 and 499 FDDs at the ridge and summit sites. The effect of increased solar radiation on the ridge and summit sites, which have very high values of potential solar radiation, combined with the wind exposure and lack of snow, are also causes for the strongly contrasting freeze-thaw regimes observed even during the cold season. The low degree of cloudiness in the mountain range, as demonstrated by the high number of cloud-free remote sensing scenes, emphasizes this effect. Potential solar radiation is high in summer, but homogeneous between sites, and does not explain the differences in diurnal thermal regimes, with very high maxima, especially at $\mathrm{T} 3$. This fact is underlined by the extreme TDD value of 1936 at T3, when compared to the 1536 and 1542 TDDs registered at the ridge and summit sites. The causes for 

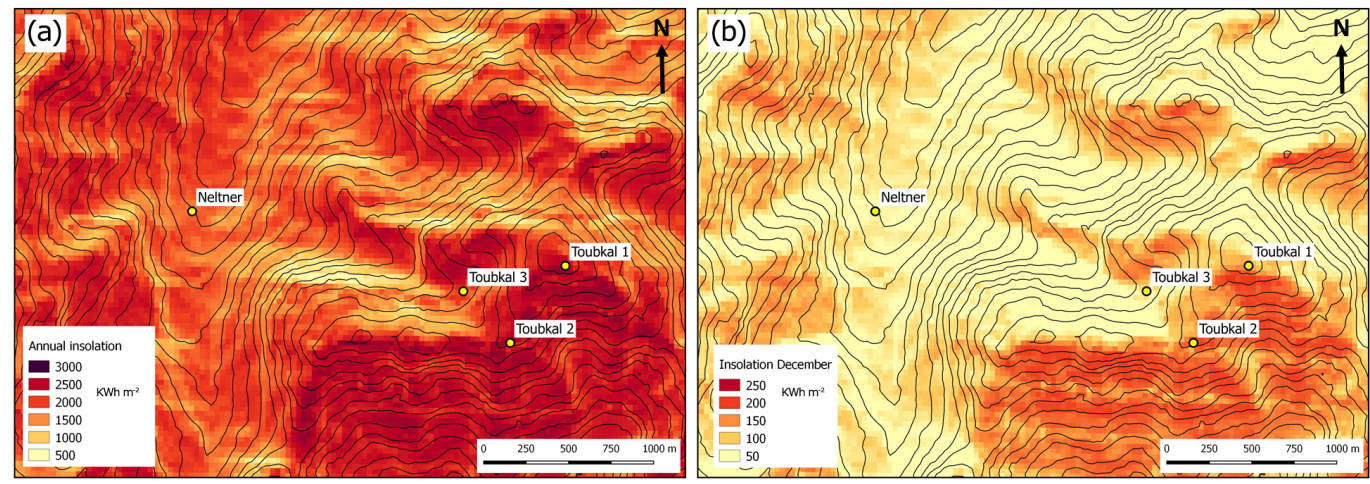

Figure 9. Modelled distribution of potential annual (a) and December (b) solar radiation in the Toubkal massif, with the locations of the ground surface temperature monitoring sites (yellow dots). Note that the colour bars are different.

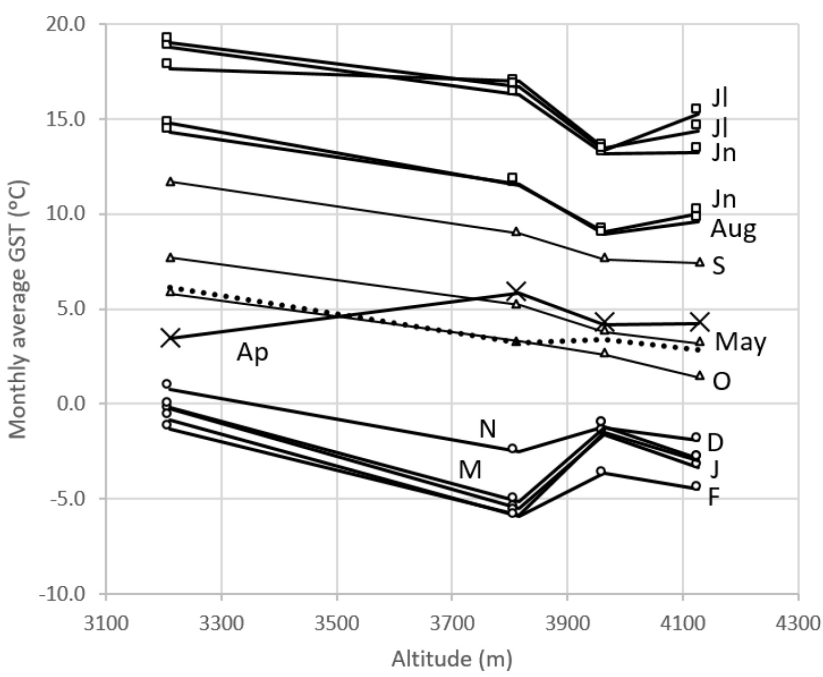

$\longrightarrow$ Group $1 \longrightarrow$ Group $2 \longrightarrow$ Group $3 \longrightarrow$ Group 4 …. mean

Figure 10. Mean monthly ground surface temperatures at the four study sites in the Toubkal massif from July 2015 to June 2016.

these differences must be the ground thermophysical properties as well as the particular morphology of site T3.

The hourly GST data allow a first insight into the ground thermal regime of the High Atlas periglacial zone. The comparison of the snow cover at different altitudes derived from the remote sensing imagery with the GST regimes confirms that the presence of the snow pack is the cause for stable temperatures close to or below $0{ }^{\circ} \mathrm{C}$ during the cold season at the different sites (Figs. 6 and 11). This fact is clear both for the period from late October to mid-April and also for the short cooling event in May. The effect is well known and has been shown for different regions. While a thin and compacted snow layer allows for fast heat transfer between the ground and the atmosphere, and, in some cases even for an increase in ground cooling due to high albedo and high ice thermal diffusivity, a thick snow pack acts as buffer between the ground and the atmosphere. If snow is thick enough, the thermal wave will be delayed in the ground (Goodrich, 1982; Staub and Delaloye, 2016; Williams and Smith, 1989). If the ground is unfrozen at depth, heat will flow towards the snow pack and the ground surface temperature will be controlled by phase change at the snow interface, generating near $0{ }^{\circ} \mathrm{C}$ isothermal regimes (Vieira et al., 2003) - the so-called zerocurtain effect (Outcalt et al., 1990). On the other hand, if the ground is colder than the snow pack or contains ice, it will generate a heat sink at depth, inducing a decrease in GST, which is a function of the insulating capacity of the snow pack, that also depends on forcing induced by the atmosphere at the snow-air interface (see Haeberli and Patzelt, 1982; Ishikawa, 2003). Recently, Kenner et al. (2017) showed from observations on a talus slope site in eastern Switzerland that the presence of buried ice can generate cold anomalies in the ground, an effect related to its high thermal conductivity and high heat capacity.

T3 shows the most remarkable thermal regime of the four sites, with low and relatively stable GST at ca. $-5.8^{\circ} \mathrm{C}$ from December 2015 to March 2016. The low temperature range reflects the insulating effect of snow cover, but small diurnal fluctuations can still be identified in the GST, with daily amplitudes of up to $1{ }^{\circ} \mathrm{C}$. For example, the hourly values at T3 from 4 to 20 December 2015 show GSTs consistently below estimated air temperatures, except for a few hours on 11 and 12 December (Fig. 12). This situation occurred throughout the snow cover period. Data also show that the thermal wave is delayed in the snowpack for about 5-6h, with the resulting GST curve being much smoother than the projected air temperatures.

Ishikawa (2003) reports two sites with GST regimes very similar to that at T3 in the Hidaka Mountains (Hokkaido, Japan), located in low-altitude openwork boulder deposits, favouring cold air drainage and air funneling in winter. The author has classified this type of setting as the extra-zonal permafrost zone. Lambiel and Pieracci (2008) also report a similar thermal regime to $\mathrm{T} 3$ at the base of a talus slope at 

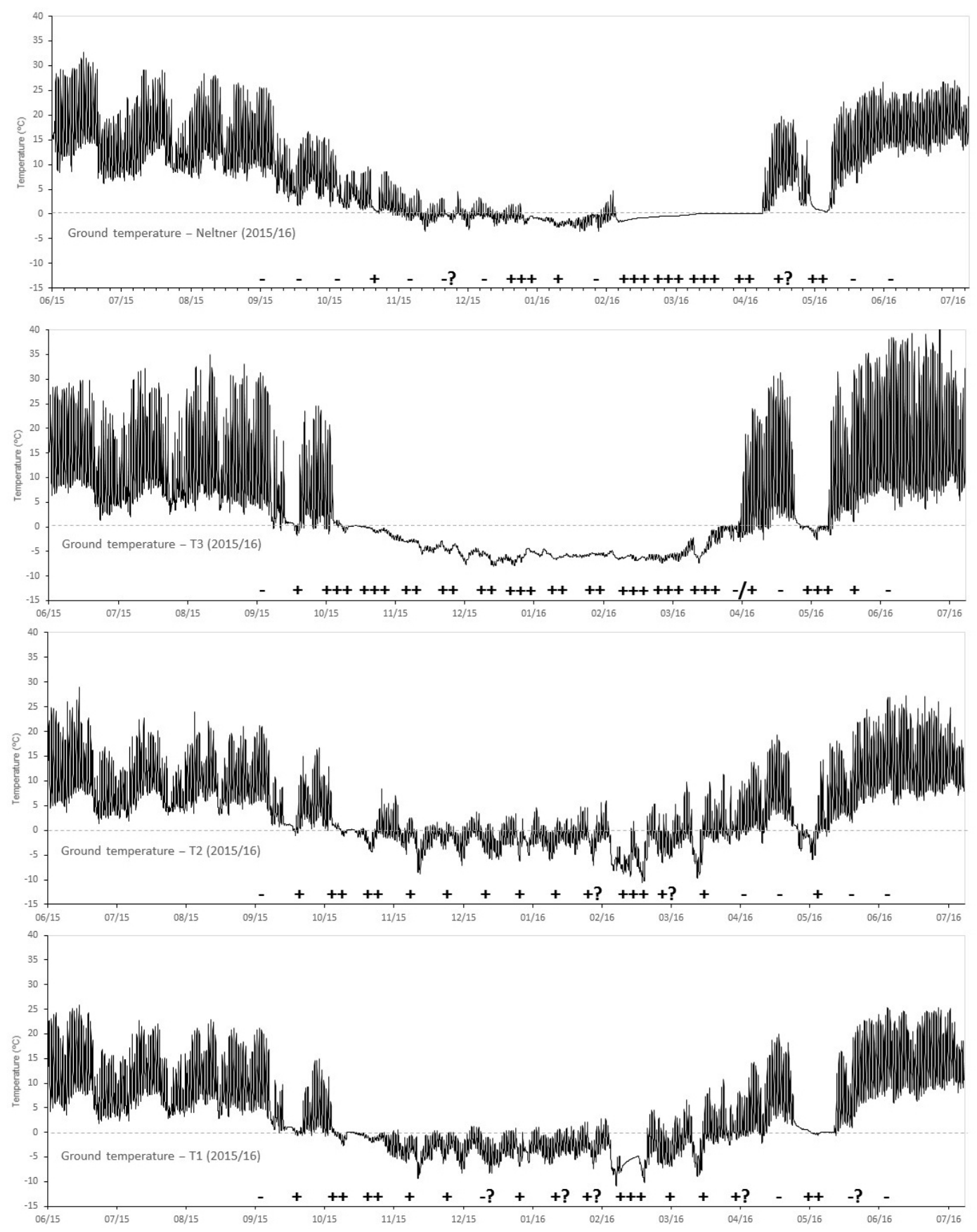

Figure 11. Ground surface temperature regimes at the four sites in the Toubkal massif. The plot shows hourly data. Symbols indicate the snow cover conditions at the date of satellite scenes: - , no snow; + , possible snow/snow margin; ++ , snow; +++ , significant snow; ?, uncertainty in classification.

low altitude in the western Swiss Alps, reporting GST below $-5{ }^{\circ} \mathrm{C}$ at the end of winter as an indicator of the probable presence of permafrost. Spring GST values lower than $-3^{\circ} \mathrm{C}$ under thick snow covers are frequently used as an indication of the probable presence of permafrost, an approach derived from the widely used bottom temperature of snow (BTS) method (Hoelzle, 1992; Lewkowicz and Ednie,
2004). Numerous cases with sporadic permafrost developing in talus slopes have been reported and the cooling process below coarse debris is well known (e.g. Delaloye et al., 2003; Delaloye and Lambiel, 2005; Gądek, 2012; Sawada et al., 2003). In a study of the Tatra Mountains (Poland and Slovakia), different GST regimes were analysed by Gądek and Kędzia (2008), who associated sites with steadily de- 


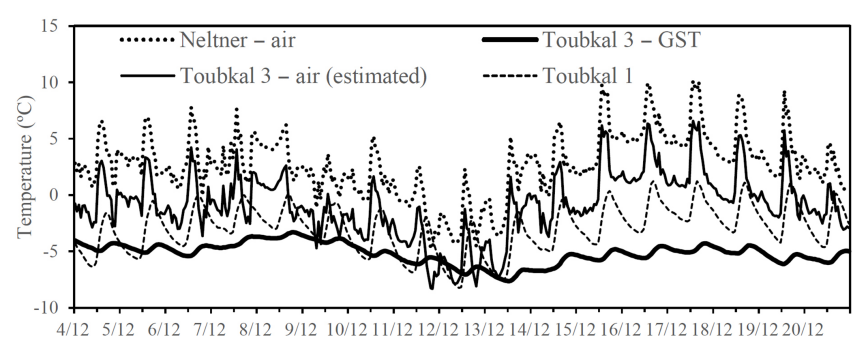

Figure 12. Example showing the estimated hourly GST regime at Toubkal 3 and comparison with air temperatures measured at Neltner and extrapolated to T3 using the observed lapse rate of $-0.59^{\circ} \mathrm{C} 100 \mathrm{~m}^{-1}$.

creasing winter GSTs to increasing snow cover, and, wherever GST dropped to below about $-5^{\circ} \mathrm{C}$, permafrost was found. The ground did not have voids, which limited cold air flow through the boulders, a situation similar to T3 in the Toubkal. Furthermore, small variations in GST during the cold season indicated that the snow insulation was not perfect. Ground cooling and snow cooling were attributed to cold air flowing over the surface in concave settings. This process, together with the low summer solar irradiation, promoted ground cooling and had a greater influence on low GST than snow thickness or elevation.

Other authors have indicated snow redistribution by avalanches as an important factor promoting cooler ground and permafrost formation at the base of slopes, since snow lasts longer at those locations, mitigating ground surface warming (Haeberli, 1975). Onaca et al. (2015) indicate this as an important effect for the maintenance of permafrost in the Retezat Mountains (Romania), where permafrost occurs at sites with MAGST below $0{ }^{\circ} \mathrm{C}$, BTS lower than $-3{ }^{\circ} \mathrm{C}$ and ground freezing index higher than $600^{\circ}$ days. Snow avalanche and rock and debris fall events have also been shown to be responsible for burial of snow and ice at the base of talus slopes, even at low altitudes (see for example Scapozza et al., 2011, or Kenner et al., 2017). Such buried ice may be preserved for long periods of time, below the climate boundary of permafrost, and acts as a heat sink promoting lower GST and may thus explain the conditions observed at T3.

Based on the literature cited above, the low and stable GSTs measured at T3 $(3815 \mathrm{~m})$ in winter are a strong indicator of the probable occurrence of permafrost. However, MAGST is relatively high at $3.2^{\circ} \mathrm{C}$, resulting from the very high summer GSTs. These are likely caused by the concave setting (little wind, direct and indirect radiation) and the thermophysical properties of the soil. The surface material is a bouldery matrix-supported deposit, with a pebbly-sandy matrix and no visible voids. This limits the interpretation of a talus-ventilation-related origin for the low GSTs and suggests conditions similar to those described by Gądek and Kędzia (2008) and by Onaca et al. (2015) in the Tatra Moun- tains. In addition, the area around $\mathrm{T} 3$ has been observed to be one of the sites with the latest snow melt. Local guides also indicate that wind redeposition of snow is an important mechanism for snow accumulation at the site. The geomorphic setting in the lower part of a talus slope indicates the possibility of ice burial by a combination of avalanching and subsequent rock fall in the past. The ground may have voids at depth, which could help explain the low temperatures, but this has not yet been verified.

The GST regimes measured at Neltner $(3220 \mathrm{~m})$ clearly indicate that permafrost is absent. The snow pack only settled in mid-February and GST became very stable around $0{ }^{\circ} \mathrm{C}$, which shows that there is no heat sink at depth, but rather a warmer unfrozen ground. Snow lasted about a week longer than at T3, possibly due to local effects, such as shading or thicker snow accumulation associated with snow drifting.

The upper sites on the ridge (T2 - $3980 \mathrm{~m}$ ) and on the summit of Toubkal $(\mathrm{T} 3-4160 \mathrm{~m})$ show short periods of stable GST during snowfall episodes, but long-lasting zero curtains did not occur after the initial one in late October, which was synchronous at T1, T2 and T3 (Fig. 11). After that episode, GSTs were irregular, ranging between $\sim 1$ and $8^{\circ} \mathrm{C}$, thus indicating the absence of snow. The lack of zero-curtain effects and the frequent freeze-thaw cycles at T2 confirm the absence of snow and indicate a very dry soil. The GST regime analysis does not allow assessing on the presence of permafrost.

The very high daily GST ranges during the warm season can be explained by the high insolation, together with the scarce moisture and rocky nature of the soil. We have no data to explain the very high GSTs at T3 with confidence, but they should be a function of local differences in soil thermophysical properties, together with the concave setting of the site, which receives more reflected and emitted radiation from the surrounding slopes and also due to a wind shelter effect. Both $\mathrm{T} 2$ and $\mathrm{T} 1$ are in convex terrain and are very wind-exposed sites, which may explain lower summer maxima than at T3.

It is possible that permafrost is present at T3, since the valley shows landforms typical of mountain permafrost, such as lobate deposits and poorly developed transverse ridges and furrows in the lower part of the scree slope (Fig. 13). The high altitude and sheltered location favouring wind-driven snow accumulation and longer lasting snow cover, together with the talus setting, also favours ice burial either by snow deposition in the past (dry snow blown into the debris voids) or by mass wasting with rockfall covering snow deposits and conserving the ice. This may have occurred a long time ago and would have led to the formation of interstitial ice facilitating the creep of the frozen talus and forming the observed solifluction and creep-related features. Amplified cooling over the snow surface due to the concave setting and cold air drainage, as observed in the Tatra Mountains, may also be a process controlling ground cooling. The longer lasting snow also provides moisture that may refreeze at depth when percolating into the debris. 


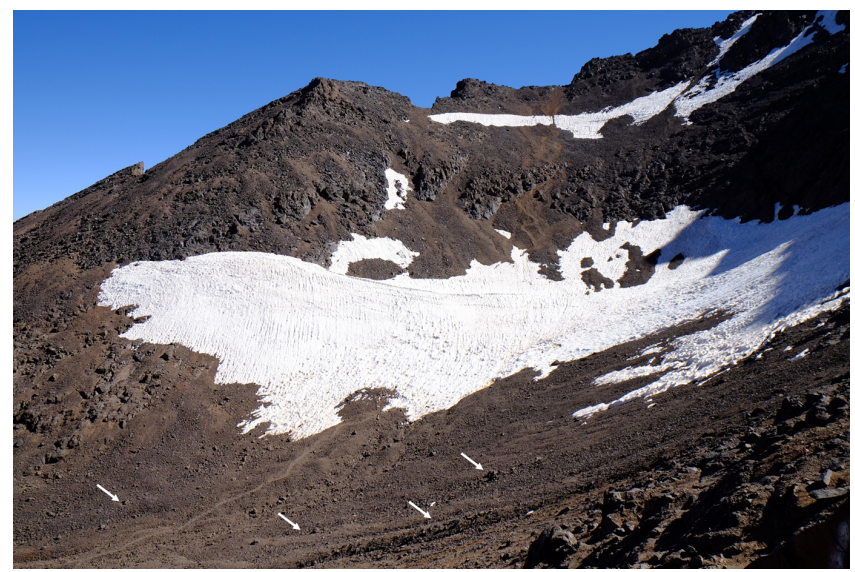

Figure 13. The Irhzer Ikhibi south valley, where the data logger Toubkal 3 was installed. The white arrows indicate arcuate boulder ridges and furrows in the talus slope. Note the large snow patch at the base of the scarp slope.

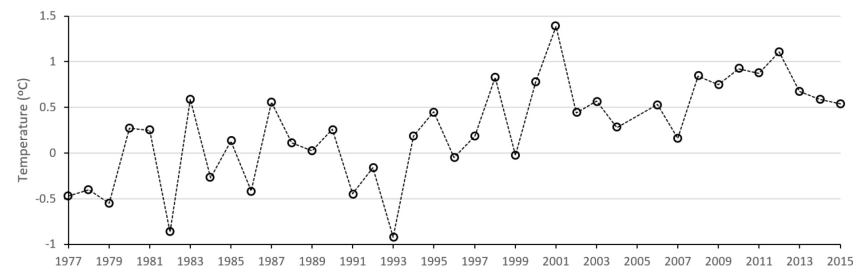

Figure 14. Estimated mean annual air temperatures at the summit of Djebel Toubkal (4167 ma.s.l.) obtained from extrapolation of temperatures from Menara (Marrakesh) using a lapse rate of $-0.59^{\circ} \mathrm{C} 100 \mathrm{~m}^{-1}$.

The extrapolation of the long-term climate records from Menara to the summit of Djebel Toubkal using a lapse

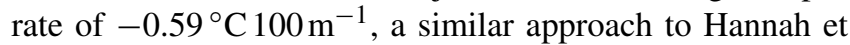
al. (2016), allows for an insight into the climate sensitivity of the high reaches of the Toubkal massif. The climate data should be interpreted with care, but it is worth noting that the extrapolation of the warming trend observed in Marrakesh, represents a gradual shift towards positive MAAT at the summit of Toubkal (Fig. 14). This suggests that any possible permafrost in the High Atlas is likely to disappear if the trend continues.

\section{Conclusions}

The measurement of GST from June 2015 to July 2016 at four sites in the Toubkal massif provided first data from the high-altitude periglacial domain of the High Atlas. The measurement period was marked by high air temperatures in December and January, with very low precipitation from November to January, causing a late onset of the winter snow cover. GSTs measured between 3210 and $4160 \mathrm{~m}$ a.s.l. showed two contrasting periods: a hot season from late May to late September and a long cold season from mid-October to mid-April. This pilot study allows for the following conclusions:

- The hot season was characterized by positive air temperatures at all sites and by very high daily GST amplitudes, with maxima reaching $40.1{ }^{\circ} \mathrm{C}$. This regime was controlled by solar radiation and by the dryness of the soil.

- The cold season was marked by either subzero GSTs or by frequent freeze-thaw cycles, depending on snow conditions.

- Frequent freeze-thaw cycles were registered at Neltner in a valley floor at $3220 \mathrm{~m}$ during the start of the cold season, until a heavy snowfall event in mid-February, inducing GST to stabilize around $0{ }^{\circ} \mathrm{C}$.

- High-altitude sites in windswept areas (T2 - 3980 and $\mathrm{T} 1-4160 \mathrm{~m}$ ) had subzero GSTs with frequent freezethaw cycles, indicating the lack of an insulating snow cover. These conditions prevailed during the whole cold season, with mean monthly GSTs below $0^{\circ} \mathrm{C}$ from November to March.

- The T3 mini-logger located in Irhzer Ikhibi south valley at $3815 \mathrm{~m}$ a.s.l. registered a remarkable GST regime with particularly high values in summer and low ones in winter. After an early onset of a stable snow pack in mid-October, GST decreased regularly until midDecember and then stabilized around ca. $-5.8^{\circ} \mathrm{C}$ lasting until late March.

- The GST regime at T3 indicates the likely presence of permafrost, which is supported by the presence of poorly developed arcuate ridges and furrows in the area. This valley site has a long-lasting snow cover due to wind accumulation and moderate potential incoming solar radiation in winter, which favours lower ground temperatures. The low winter GSTs may result from the joint effects of snow, cold air flow within the talus and over the snow surface, and from the possible presence of interstitial/buried ice resulting from rockfall events on snow.

- Topography, possibly together with site-specific masswasting conditions, overcomes the driving effect of altitude on GST in the Toubkal massif.

These results should be interpreted with care, and, although the preliminary data suggest the presence of permafrost, more observations are needed for an accurate assessment. The presence of permafrost at $3800 \mathrm{~m}$ in the Djebel Toubkal massif could become spatially significant for the High Atlas with its high mountains and complex topography in both the Toubkal and M'Goun ranges. 


\section{Outlook}

For the continuation of this pilot study, forthcoming research should target the following: (i) electrical resistivity surveying to identify the presence and quantify the volume of ground ice, (ii) installing a larger number of GST loggers in different settings around T3, (iii) installing an air temperature logger at T3 to assess the possible shading effects of the topography on air temperature and GSTs, and (iv) the drilling of a borehole to monitor ground temperatures at depth and possibly obtain ice samples.

Soil samples would possibly allow the analysis of permafrost ice as a palaeoenvironmental archive, and dating it would help to elucidate the history of mass wasting at the site. Given the warming trend in the region, further research is needed at an interdisciplinary level, since possible permafrost remnants could quickly disappear and may be the last ones in North Africa. On the other hand, if buried ground ice is present, it may have been conserved for a long time despite climate warming.

Data availability. Air and ground surface temperature data are available at http://www.ceg.ulisboa.pt/vieira/vieira_et_al_2017_ DATA.xlsx.

Competing interests. The authors declare that they have no conflict of interest.

Special issue statement. This article is part of the special issue "The evolution of permafrost in mountain regions". It does not belong to a conference.

Acknowledgements. Special thanks are due to Philip Hughes, who provided valuable advice on routes and logistics for the Toubkal massif and information on the geomorphology of the region. Warmest thanks to Sebastião Vieira, who participated in the field season of 2015 and helped with the setting of the loggers, for his fantastic company and patience. Mustapha Asquarray (Dar Assarou) from Imlil provided excellent guiding services and support in the Toubkal region, with Ibrahim ait Tadrart Buff and Mohammed Boyikd providing mule transport support. We thank the Ait Elkadi family guardians of the Neltner hut and Hsin Nsliman at the Sidi Chamharouch Cafe for the surveillance of the air temperature/RH loggers. Hassan Michalou is thanked for helping with the air temperature mini-logger at the summit of Toubkal. The manuscript benefited from the comments of Enrique Serrano and Benno Staub, who conducted the review and whom we thank. Marcia Phillips is thanked for the detailed comments, discussion and editorial review, which contributed to significantly improving the final version of the manuscript. This research benefited from support of the bilateral project COLDATLAS - "Does permafrost occur in the high mountains of North Africa?" funded by the FCT/CNRST (Portugal-Morocco), with partial funding from the CEG/IGOT - Universidade de Lisboa.

Edited by: Marcia Phillips

Reviewed by: Benno Staub and Enrique Serrano

\section{References}

Arboleya, M. L., Teixell, A., Charroud, M., and Julivert, M.: A structural transect through the High and Middle Atlas of Morocco, J. Afr. Earth Sci., 39, 319-327, https://doi.org/10.1016/j.jafrearsci.2004.07.036, 2004.

Badri, W., Gauquelin, T., Minet, J., and Savoie, J. M.: Données météorologiques nouvelles sur le massif de Oukaimeden $(2570 \mathrm{~m}$, Haut Atlas de Marrakech, Maroc): un exemple de climat de haute montagne méditerranéenne, Publications de l'Association Internationale de e Climatologie, 7, 190-198, 1994.

Biskaborn, B. K., Lanckman, J.-P., Lantuit, H., Elger, K., Streletskiy, D. A., Cable, W. L., and Romanovsky, V. E.: The new database of the Global Terrestrial Network for Permafrost (GTN-P), Earth Syst. Sci. Data, 7, 245-259, https://doi.org/10.5194/essd-7-245-2015, 2015.

Boudhar, A., Hanich, L., Boulet, G., Duchemin, B., Berjamy, B., and Chehbouni, A.: Evaluation of the Snowmelt Runoff Model in the Moroccan High Atlas Mountains using two snow-cover estimates, Hydrol. Sci. J., 54, 1094-1113, https://doi.org/10.1623/hysj.54.6.1094, 2009.

Boudhar, A., Boulet, G., Hanich, L., Sicart, J. E., and Chehbouni, A.: Energy fluxes and melt rate of a seasonal snow cover in the Moroccan High Atlas, Hydrol. Sci. J., 1, 931-943, https://doi.org/10.1080/02626667.2014.965173, 2016.

Chardon, M. and Riser, J.: Formes et processus géomorphologiques dans le Haut-Atlas marocain, Rev. Geogr. Alp., 69, 561-582, 1981.

Cheggour, A.: Mesures de l'érosion hydrique à différentes échelles spatiales dans un bassin versant montagneux semi-aride et spatialisation par des S.I.G.: Application au bassin versant de la Rhéraya, Haut Atlas, Maroc, Cady Ayyad, Marrakesh, 2008.

Couvreur, G.: Les formations périglaciaires du Haut Atlas central marocain, Revue de Géographie du Maroc, 10, 47-50, 1966.

Delaloye, R. and Lambiel, C.: Evidence of winter ascending air circulation throughout talus slopes and rock glaciers situated in the lower belt of alpine discontinuous permafrost (Swiss Alps), Norsk. Geogr. Tidsskr., 59, 194-203, https://doi.org/10.1080/00291950510020673, 2005.

Delaloye, R., Reynard, E., Lambiel, C., Marescot, L., and Monnet, R.: Thermal anomaly in a cold scree slope (Creux du Van, Switzerland), in: Proceedings 8th Int. Conf. Permafrost, Zurich 2003, edited by: Phillips, M., Springman, S. M., and Arenson, L. U., A.A. Balkema, 175-180, 2003.

de Martonne, E.: Les formes glaciaires sur le versant nord du Haut Atlas, Ann. Georgr., 33, 296-302, 1924.

Dresch, J.: Recherches sur l'évolution du relief dans le Massif Central du Grand Atlas: le Haouz et le Sous, Arrault et Cie, Maitres Imprimeurs, Tours, 1941.

ESA: Sentinel-2 User Handbook, ESA Standard Document, available at: https://sentinels.copernicus.eu/documents/247904/ 685211/Sentinel-2_User_Handbook, 1, 64 pp., 2015. 
Ferreira, A., Vieira, G., Ramos, M., and Nieuwendam, A.: Ground temperature and permafrost distribution in Hurd Peninsula (Livingston Island, Maritime Antarctic): An assessment using freezing indexes and TTOP modelling, CATENA, 149, 560-571, https://doi.org/10.1016/j.catena.2016.08.027, 2016.

Gądek, B.: Debris slopes ventilation in the periglacial zone of the Tatra Mountains (Poland and Slovakia): The indicators, Cold Reg. Sci. Technol., 74-75, 1-10, https://doi.org/10.1016/j.coldregions.2012.01.007, 2012.

Gądek, B. and Kędzia, S.: Winter ground surface temperature regimes in the zone of sporadic discontinuous permafrost, Tatra Mountains (Poland and Slovakia), Permafrost Periglac., 19, 315321, https://doi.org/10.1002/ppp.623, 2008.

Giorgi, F. and Lionello, P.: Climate change projections for the Mediterranean region, Global Planet. Change, 63, 90-104, https://doi.org/10.1016/j.gloplacha.2007.09.005, 2007.

Goodrich, L. E.: The influence of snow cover on the ground thermal regime, Can. Geotech. J., 19, 421-432, https://doi.org/10.1139/t82-047, 1982.

Gruber, S. and Haeberli, W.: Mountain Permafrost, in: Permafrost Soils, edited by: Margesin, R., Springer Berlin Heidelberg, Volume 16 of the series Soil Biology, 33-44, 2009.

Gubler, S., Fiddes, J., Keller, M., and Gruber, S.: Scaledependent measurement and analysis of ground surface temperature variability in alpine terrain, The Cryosphere, 5, 431-443, https://doi.org/10.5194/tc-5-431-2011, 2011.

Haeberli, W.: Untersuchungen zur Verbreitung von Permafrost zwischen Flüelapass und Piz Grialetsch (Graubünden)), Mitteilung der Versuchsanstalt für Wasserbau, Hydrologie und Glaziologie, ETH Zurich, Nr. 17, 221 pp., 1975.

Haeberli, W. and Patzelt, G.: Permafrostkartierung im gebiet der Hochebenkar-blockgletscher, Obergurgl, Otztaler Alpen, Zeitschrift für Gletscherkunde und Glazialgeologie, 18, 127150, 1982.

Haeberli, W., Noetzli, J., Arenson, L., Delaloye, R., Gärtner-Roer, I., Gruber, S., Isaksen, K., Kneisel, C., Krautblatter, M., and Phillips, M.: Mountain permafrost: development and challenges of a young research field, J. Glaciol., 56, 1043-1058, 2010.

Hannah, G., Hughes, P. D., and Gibbard, P. L.: Pleistocene plateau ice fields in the High Atlas, Morocco, in: Quaternary glaciation in the Mediterranean mountains, edited by: Hughes, P. D. and Woodward, J. C., Geological Society, London, Special Publications, 433, 25-53, https://doi.org/10.1144/SP433.12, 2016.

Hoelzle, M.: Permafrost occurrence from BTS measurements and climatic parameters in the eastern Swiss Alps, Permafrost Periglac., 3, 143-147, https://doi.org/10.1002/ppp.3430030212, 1992.

Hu, W., Zhang, Q., Tian, T., Cheng, G., An, L., and Feng, H.: The microbial diversity, distribution, and ecology of permafrost in China: a review, Extremophiles, 19, 693-705, https://doi.org/10.1007/s00792-015-0749-y, 2015.

Hughes, P. D.: Little Ice Age glaciers in the Mediterranean mountains, Méditerranée, 122, 63-79, https://doi.org/10.4000/mediterranee.7146, 2014.

Hughes, P. D. and Woodward, J.: Timing of glaciation in the Mediterranean mountains during the last cold stage, J. Quaternary Sci., 23, 575-588, https://doi.org/10.1002/jqs.1212, 2008.

Hughes, P. D., Fenton, C. R., and Gibbard, P. L.: Quaternary Glaciations of the Atlas Mountains, North Africa, in: Develop- ments in Quaternary Science, Elsevier, USA, 15, 1065-1074, https://doi.org/10.1016/B978-0-444-53447-7.00076-3, 2011.

Hughes, P. D., Fink, D., Fletcher, W. J., and Hannah, G.: Catastrophic rock avalanches in a glaciated valley of the High Atlas, Morocco: ${ }^{10} \mathrm{Be}$ exposure ages reveal a $4.5 \mathrm{ka}$ seismic event, Geol. Soc. Am. Bull., 126, 1093-1104, https://doi.org/10.1130/B30894.1, 2014.

Ishikawa, M.: Thermal regimes at the snow-ground interface and their implications for permafrost investigation, Geomorphology, 52, 105-120, https://doi.org/10.1016/S0169-555X(02)00251-9, 2003.

Jansson, J. K. and Taş, N.: The microbial ecology of permafrost, Nat. Rev. Microbiol., 12, 414-425, https://doi.org/10.1038/nrmicro3262, 2014.

Kenner, R., Phillips, M., Hauck, C., Hilblich, C., Mulsow, C., Buhler, Y., Stoffel, A., and Buchroithner, C.: New insights on permafrost genesis and conservation in talus slopes based on observations at Flüelapass, Eastern Switzerland, Geomorphology, 290, 110-113, https://doi.org/10.1016/j.geomorph.2017.04.011, 2017.

Knippertz, P., Christoph, M., and Speth, P.: Long-term precipitation variability in Morocco and the link to the large-scale circulation in recent and future climates, Meteorol. Atmos. Phys., 83, 67-88, https://doi.org/10.1007/s00703-002-0561-y, 2003.

Lacelle, D. and Vasil'chuk, Y. K.: Recent Progress (2007-2012) in Permafrost Isotope Geochemistry, Permafrost Periglac., 24, 138145, https://doi.org/10.1002/ppp.1768, 2013.

Lambiel, C. and Pieracci, K.: Permafrost distribution in talus slopes located within the alpine periglacial belt, Swiss Alps, Permafrost Periglac., 19, 293-304, https://doi.org/10.1002/ppp.624, 2008.

Lewkowicz, A. G. and Ednie, M.: Probability mapping of mountain permafrost using the BTS method, Wolf Creek, Yukon Territory, Canada, Permafrost Periglac., 15, 67-80, https://doi.org/10.1002/ppp.480, 2004.

Marchane, A., Jarlan, L., Hanich, L., Boudhar, A., Gascoin, S., Tavernier, A., Filali, N., Le Page, M., Hagolle, O., and Berjamy, B.: Assessment of daily MODIS snow cover products to monitor snow cover dynamics over the Moroccan Atlas mountain range, Remote Sens. Environ., 160, 72-86, https://doi.org/10.1016/j.rse.2015.01.002, 2015.

Mark, B. G. and Osmaston, H. A.: Quaternary glaciation in Africa: Key chronologies and climatic implications, J. Quaternary Sci., 23, 589-608, https://doi.org/10.1002/jqs.1222, 2008.

Montanari, B.: The Future of Agriculture in the High Atlas Mountains of Morocco: The Need to Integrate Traditional Ecological Knowledge, in: The Future of Mountain Agriculture, edited by: Mann, S., Springer Berlin Heidelberg, 51-72, 2013.

N'da, A. B., Bouchaou, L., Reichert, B., Hanich, L., Ait Brahim, Y., Chehbouni, A., Beraaouz, E. H., and Michelot, J.-L.: Isotopic signatures for the assessment of snow water resources in the Moroccan high Atlas mountains: contribution to surface and groundwater recharge, Environmental Earth Sciences, 75, 755, https://doi.org/10.1007/s12665-016-5566-9, 2016.

Oliva, M., Gómez-Ortiz, A., Salvador-Franch, F., Salvà-Catarineu, M., Palacios, D., Tanarro, L., Ramos, M., Pereira, P., and RuizFernández, J.: Inexistence of permafrost at the top of the Veleta peak (Sierra Nevada, Spain), Sci. Total Environ., 550, 484-494, https://doi.org/10.1016/j.scitotenv.2016.01.150, 2016a. 
Oliva, M., Serrano, E., Gómez-Ortiz, A., González-Amuchastegui, M. J., Nieuwendam, A., Palacios, D., Pérez-Alberti, A. P., Pellitero-Ondicol, R., Ruiz-Fernández, J., Valcárcel, M., Vieira, G., and Antoniades, D.: Spatial and temporal variability of periglaciation of the Iberian Peninsula, Quaternary Sci. Rev., 137, 176-199, https://doi.org/10.1016/j.quascirev.2016.02.017, 2016 b.

Onaca, A., Ardelean, A. C., Urdea, P., Ardelean, F., and Sîrbu, F.: Detection of mountain permafrost by combining conventional geophysical methods and thermal monitoring in the Retezat Mountains, Romania, Cold Reg. Sci. Technol., 119, 111-123, https://doi.org/10.1016/j.coldregions.2015.08.001, 2015.

Outcalt, S. I., Nelson, F. E., and Hinkel, K. M.: The zerocurtain effect: Heat and mass transfer across an isothermal region in freezing soil, Water Resour. Res., 26, 1509-1516, https://doi.org/10.1029/WR026i007p01509, 1990.

PERMOS: Permafrost in Switzerland 2010/2011 to 2013/2014, edited by: Noetzli, J., Luethi, R., and Staub, B., Cryospheric Commission, Swiss Academy of Sciences, Glaciological Report Permafrost No. 12-15, 85 pp., 2016.

Peyron, M.: Les chutes de neige dans l'Atlas marocain, Rev. Geogr. Alp., 68, 237-254, https://doi.org/10.3406/rga.1980.2203, 1980.

Rangecroft, S., Harrison, S., Anderson, K., Magrath, J., Castel, A. P., and Pacheco, P.: Climate change and water resources in arid mountains: An example from the bolivian andes, Ambio, 42, 852-863, https://doi.org/10.1007/s13280-013-0430-6, 2013.

Rauh, W.: Vegetationsstudien im Hohen Atlas un dessen Vorland, Springer-Verlag, Sitzungsber.Heidelberg 52, 4-118, 1952.

Robinson, D. A. and Williams, R. B. G.: Sandstone weathering in the High Atlas, Morocco, Z. Geomorphol., 36, 413-429, 1992.

Ros, R. M., Cano, M. J., Muñoz, J., and Guerra, J.: Contribution to the bryophyte flora of Morocco: the Jbel Toubkal, J. Bryol., 22, 283-289, 2000.

Salvador Franch, F., Gómez Ortiz, A., Salvà Catarineu, M., and Palacios Estremera, D.: Caracterización térmica de la capa activa de un glaciar rocoso en medio periglaciar de alta montaña mediterránea?: El ejemplo del Corral del Veleta (Sierra Nevada, España), Cuadernos de Investigación Geográfica, 37, 25 , https://doi.org/10.18172/cig.1255, 2011.

Sawada, Y., Ishikawa, M., and Ono, Y.: Thermal regime of sporadic permafrost in a block slope on Mt. Nishi-Nupukaushinupuri, Hokkaido Island, Northern Japan, Geomorphology, 52, 121-130, https://doi.org/10.1016/S0169-555X(02)00252-0, 2003.

Scapozza, C., Lambiel, C., Baron, L., Marescot, L., and Reynard, E.: Internal structure and permafrost distribution in two alpine periglacial talus slopes, Valais, Swiss Alps, Geomorphology, 132, 208-221, https://doi.org/10.1016/j.geomorph.2011.05.010, 2011.
Schulz, O. and de Jong, C.: Snowmelt and sublimation: field experiments and modelling in the High Atlas Mountains of Morocco, Hydrol. Earth Syst. Sci., 8, 1076-1089, https://doi.org/10.5194/hess-8-1076-2004, 2004.

Serrano, E., Morales, C., González-Trueba, J. and Martín, R.: Cartografía del permafrost de montaña en los Pirineos españoles, Finisterra. Revista Portuguesa de Geografia, 44, 45-54, https://doi.org/10.18055/Finis1376, 2009.

Simonneaux, V., Cheggour, A., Deschamps, C., Mouillot, F., Cerdan, O., and Le Bissonnais, Y.: Land use and climate change effects on soil erosion in a semi-arid mountainous watershed (High Atlas, Morocco), J. Arid Environ., 122, 64-75, https://doi.org/10.1016/j.jaridenv.2015.06.002, 2015.

Smith, S. and Brown, J.: Essential Climate Variables: Permafrost and seasonally frozen ground, GTOS, 62, 19 pp., 2009.

Staub, B. and Delaloye, R.: Using Near-Surface Ground Temperature Data to Derive Snow Insulation and Melt Indices for Mountain Permafrost Applications, Permafrost Periglac., 248, 237248, https://doi.org/10.1002/ppp.1890, 2016.

Tanarro, L. M., Hoelzle, M., García, A., Ramos, M., Gruber, S., Gómez, A., Piquer, M., and Palacios, D.: Permafrost distribution modelling in the mountains of the Mediterranean: Corral del Veleta, Sierra Nevada, Spain, Norsk Geogr. Tidsskr., 55, 253 260, https://doi.org/10.1080/00291950152746612, 2001.

USGS: Landsat 8 (L8) Data users handbook, U.S. Geological Survey (USGS), LSDS-1574, Version 2.0, 2016.

Vieira, G., Mora, C., and Ramos, M.: Ground temperature regimes and geomorphological implications in a Mediterranean mountain (Serra da Estrela, Portugal), Geomorphology, 52, 57-72, https://doi.org/10.1016/S0169-555X(02)00248-9, 2003.

Wilche, K.: Klimamorphologische und talgeschichtliche studien im M'Goungebiet, Mitteilungen der geologischen Gesellschaft in Wien, 95, 4-41, 1953.

Williams, P. J. and Smith, M. W.: The Frozen Earth, Cambridge University Press, Cambridge, 1989.

Yoshikawa, K. (Ed.): Africa, Kilimanjaro, in: Permafrost in our time, University of Alaska Fairbanks, Valencia, California, 238239, 2013.

Zahour, G., El Hadi, H., Tahiri, A., Zerhouni, Y., Alikouss, S., Zahour, R., and Reddad, A.: The Late Neoproterozoic Continental Tholeiitic Basalts of the Toubkal Inlier (Western High-Atlas, Morocco): A Post-Pan-African Rifting Witness in the Northern Margin of the West African Craton, Open Journal of Ecology, 6, 509-516, https://doi.org/10.4236/oje.2016.68048, 2016. 